\title{
Characteristics Of Adhesive Firmness Of Tannin Resorcinol Formaldehyde From Johar Sawdust Extract As Adhesive On Lamina Wood
}

\author{
Agestya Hernawati, Suyatno Sutoyo \\ Departement of Chemistry, Faculty of Mathematics and Natural Sciences \\ Universitas Negeri Surabaya \\ J1. Ketintang Surabaya, Indonesia \\ suyatno@unesa.ac.id
}

\begin{abstract}
This research has been done by testing the adhesive firmness of resorcinol formaldehyde from Johar sawdust extract. This study aims to determine the best adhesive characteristic made of the mixture of Johar sawdust extract with resorcinol and copolymerized with formaldehyde. The composition comparison of tannin extract, resorcinol, and formaldehyde extracts are $3: 1.4: 1 ; 3: 1,6: 1 ; 3: 1.8: 1$, and 3 : 2.0: 1 gram. The adhesive firmness test, physical test and chemical test of for lamina wood aims to determine the quality of the adhesive result. Based on the test result of adhesive firmness of lamina wood was obtained the best value from composition ratio of $3: 1,6: 2$ is equal to $115,37 \mathrm{~kg} / \mathrm{cm} 2$, which has the physical characteristics of brownish red liquid, phenol typical odor, has a viscosity of $\mathbf{2 . 8 2}$ poise, mass type equal to $1.176 \mathrm{~g} / \mathrm{mL}$, $\mathrm{pH}$ equal to 11.02 , solid resin content equal to $43.08 \%$ and formaldehyde emission levels equal to $0.295 \mathrm{mg} / \mathrm{L}$. The value of adhesive firmness which obtained is appropriate with SNI (1998) SNI (1998) and JAS standard (1996).
\end{abstract}

Keywords: Johar Wood, adhesives, tannins, resorcinol, formaldehyde, and lamina wood

\section{INTRODUCTION}

Nowdays, wood holds an important role in various aspects of society. Indirectly, it can not be denied that the dependence of human on wood is very high bacause to fullfil the daily needs such as the production of frame, doors, tables, chairs, cupboards, craft materials, or household furniture. In fact, the availability of the wood in nature is also decreasing as the population of human increases [1]. At this time, industries which is active on field forest products especially on wood processing faced the problem of raw materials availability. The high request of the wood-stuff products is not supported by the availability of satisfied raw materials. So the product based on wood is limited and the price becomes more expensive. Acoording the Ministry of Environment (2007), the current national wood needs about 57,1 million $\mathrm{m}^{3}$ per year with the capability of natural forests and plants forest provide about 45.8 million $\mathrm{m}^{3}$ per year. Based on these conditions, there is effected on wood deficit demand about $11.3 \mathrm{~m}^{3}$ per year which encourage the development of composite product as an alternative to fullfil the needs of forest wood industries [2].

Laminasi wood is a panel wood made by glued two layers of wood or more with the direction of all layers almost parallel [3]. Therefore, the role of adhesive hold big part in wood processing industries with the production of various composite wood such as lamina wood.

In Indonesia, there has been more than hundreds of composite wood processing industries which almost of them used adhesive of urea formaldehyde (UF), phenol formaldehyde (PF), and melamine formaldehyde (MF). The most commonly adhesive produced in Indonesia are synthetic adhesive such as UF, PF, and MF to fullfil the needs of plywood industries, particle board, and lamina veneer. The use of synthetic adhesive can produce formaldehyde emissions that danger the human health [4].

One source that has potential to match the quality of phenol formaldehyde adhesive material is adhesive which the material originally from the tanin. According to Pizzi (1995), the condensed tannis cover $90 \%$ of total commercial wood production. Tanin which has natural phenolic characteristics can be an opportunity in the industry, because they do not depend on the price of petoleum as genarally in the manufacture of adhesive production [5].

Johar is one of the Indonesia's biological various plants from the family of Caesalpiniaceae and the Cassia genus which is widely cultivated in Java Island. This plant can reach a height of $20 \mathrm{~m}$, the stem is round, hard wood, and the leaves are even pinnate-shaped. In the stem, it contains several chemical compounds such as tannis, anthraquinone, lignin, hydrocynate pentose, and others (Kardono dan Broto, 2000) [6].

Tannins belongs to a natural polymer consisting of flavonoid monomer units. The condensed tannins have strong affinity for resorcinol and formaldehyde under basic conditions, forming a copolymer that can be used as an adhesive. The addition of resorcinol serves to bind the residual formaldehyde groups that do not react with tannins so that their formaldehyde emissions can be reduced [7].

Based on the description of the background that has been presented, the researcher will examine the effect of variation of resorcinol mass on the formaldehyde resin tannin resin formed and determine the adhesive which produce the best adhesive hardness properties, including solid resin content, viscosity, $\mathrm{pH}$, visual, density, formaldehyde emission, function, degree of crystallinity, and melt transition phase of the formaldehyde resin tannin resin produced. 


\section{MATERIALS AND METHODS}

\section{A. Materials}

Materials used in this research are sawdust of Johar wood obtained in Tirta Village, Karanganyar Subdistrict, Solo Regency, Central Java, technical resorcinol, technical formaldehyde, $10 \% \mathrm{NaOH}, \mathrm{NaOH} 50 \%, 96 \%$ ethanol, $\mathrm{KBr}$ pa, $\mathrm{FeCl} 3$, acetyl acetone, 20\% ammonium acetate and aquadest

\section{B. Instruments}

The instrument used in this research are a set of extraction tools with maceration method, Buchner funnel, rotary vacuum evaporator (Heidolp laborata 4001), a set of thin layer chromatography (TLC) and vacuum liquid chromatography (VLC), Fisher John melting point apparatus, UV spectrophotometer (Shimadzu Pharma Spec.UV-1700), IR spectrophotometer (Perkin Elmer USA 89485) and mass spectrophotometer (Shimadzu QP-2010S), and other glass tools.

\section{Tanin Extraction from Johar Wood Sawdust}

The Johar wood sawdust was sieved with a 40 mesh sieve, then weighed as much as 40 grams inserted in a beaker containing $96 \%$ ethanol of 160 grams. The extraction was carried out using the inflection method heated at $70^{\circ} \mathrm{C}$ for 3 hours. The liquid is separated from the remaining sawdust of Johar wood and processed by evaporation for removing the ethanol [7]

\section{Synthesis of Tanin Resorcinol Formaldehyde}

The process of formaldehyde tannin resin making is done as follows: 180 grams of tannin is mixed with 6 $\mathrm{mL} 10 \% \mathrm{NaOH}$ in a cup glass and stirred at room temperature. Then $50 \% \mathrm{NaOH}$ liquid of $1.5 \mathrm{ml}$ was added while stirring until $\mathrm{pH}$ reached 10 . The formed liquid is then spiked with rescinol bit by bit and stirred until homogeneous. The liquid was conditioned to a $\mathrm{pH}$ of 11 by adding $50 \% \mathrm{NaOH}$ liquid of $30 \mathrm{~mL}$, then adding a $37 \%$ formaldehyde liquid while stirring. Then a $24 \mathrm{~mL}$ liquid of $10 \% \mathrm{NaOH}$ was inserted, and the mixtured liquid was stirred again until the $\mathrm{pH}$ of the liquid became $\mathrm{pH}$ 11. The reaction was carried out at room temperature. The composition of the TaninResalcinol-Formaldehyde mixture prepared is $3: 0.5: 1$; 3: $0.9: 1 ; 3: 1,2: 2 ; 3: 1,6: 1 ; 3: 2.0: 1$ [8]. The composition of tannins, resorcinol, and formaldehyde is expressed in grams.

\section{E. Testing of Physical Properties and Chemical Adhesives}

\section{- The Testing of Adhesive Firmness Lamina}

Lamina wood making consists of two wooden slats (board) which is glued with the direction of all layers almost parallel, made from camphor wood about $(10 \times 3 \times 0,2) \mathrm{cm}$. Before covered by adhesive, wood dried in the oven until the water content reached $12 \%$, shriveled, and sanded. Adhesive covering processed is performed on one of the board surfaces evenly using the brush and left for 5-10 minutes for the adhesive seep into the wood. Then glue the wood with a pair of wood that is not covered by adhesive on the surface and leave for 10-15 minutes. Furthermore, the forging process is done using a press tool for 3 hours in order to forming a strong bond between the two woods. Finally, testing of hardness of adhesive lamina wood using Autograph instrument. The value of adhesive firmness is obtained using the formula $\mathrm{KR}=\mathrm{P} / \mathrm{A}$ where $\mathrm{KR}$ is Hardness of Adhesive $(\mathrm{Kg} / \mathrm{cm} 2)$, $\mathrm{P}$ is the maximum shear load $(\mathrm{Kg})$, and $\mathrm{A}$ is the area of the shear $(\mathrm{cm} 2)$ [10].

\section{RESULTS AND DISCUSSION}

\section{A. Tannin Extraction Result from Johar Wood Sawdust}

In this research, the researcher used the wood sawdust waste from the furniture industry in Tirta Village, Karanganyar Subdistrict, Solo, Central Java to taken the extract tannin. The sawdust waste obtained was sieved using a 40 mesh sieve. Extraction process using infusa method. Johar wood sawdust as much as 40 grams mixed with ethanol with a ratio of $1: 4(\mathrm{~b} / \mathrm{b})$, then heated at $70^{\circ} \mathrm{C}$ for 3 hours. After that, it is filtered using a Buchner funnel and taken the filtrate. The residue from the extraction process is repeated 3 times with the same ethanol volume. Next process is the result of filtrate is evaporated using a rotary evaporator to obtain a thickened tannin extract.

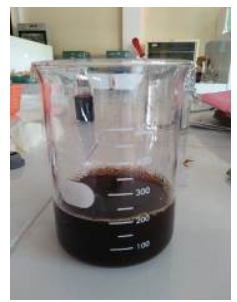

Figure 1. Tanin Sawdust Extract of Lamina Wood (Cassia siamea Lamk)

A qualitative test to analyze the presence of tannins in the extract can be done by boiling $1 \mathrm{~mL}$ of extract sample with $20 \mathrm{~mL}$ of water over a water bath, then filtered. The obtained filtrate was added 2-3 drops of 1\% $\mathrm{FeCl} 3$ liquid because of the greenish brown color, the extract contained tannin.

Figure 2. The Qualitative Test of Tanin Extract

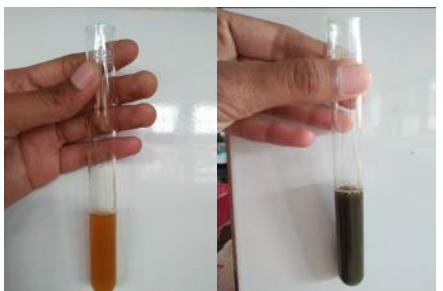

Lamina Wood 1) The Extract before tested 2) the Extract after tested

Based on the results of the test using $\mathrm{FeCl} 3$, it can be seen that the Johar sawdust extract contains tannin. This is because the phenol group of phenolic compounds 
complexes with $\mathrm{Fe}_{3}{ }^{+}$ions from $\mathrm{FeCl}_{3}$ greenish. The phenolic compound is a compound consisting of an aromatic ring and a hydroxy group $(-\mathrm{OH})$ of one or more, which in this case is a tannin [11].

$$
\left.\mathrm{FeCl}_{3(\mathrm{aq})}+6 \mathrm{ArOH}_{(\mathrm{s})} \underset{6 \mathrm{H}^{+}(\mathrm{Fe})}{\rightarrow}(\mathrm{OAr})_{6}\right]_{(\mathrm{aq})}^{3}+3 \mathrm{Cl}_{(\mathrm{aq})}^{-}+
$$

Figure 3. Reaction Of Phenolic Fitochemical Testing [11]

\section{B. Synthesis of Formaldehyde Resorcinol Tannin Adhesive} (TRF).

In this research, formaldehyde resorcinol tannin adhesion was done using blending method. The blending method is mixing two or more materials without change the chemical structure. In this study, the formaldehyde resorcinol tannin was made from a mixture of tannin extract from Johar wood, resorcinol, and formaldehyde. The composition of formaldehyde resorcinol tannin adhesion is based on the Santoso (2003) study on the synthesis and characterization of lignin resorcinol formaldehyde as lamina wood adhesive [8], and presented in Table 4.1

Table 1. Comparison Of Formaldehyde Resorcinol Tannin Adhesion

\begin{tabular}{|c|c|c|}
\hline $\begin{array}{c}\text { The Densisty of } \\
\text { Tannin Extract } \\
\text { Lamina Wood } \\
\text { (gram) }\end{array}$ & $\begin{array}{c}\text { Recorcinol } \\
\text { (gram) }\end{array}$ & $\begin{array}{c}\text { Formaldehyde } \\
\text { (gram) }\end{array}$ \\
\hline 3 & 1,4 & 1 \\
\hline 3 & 1,6 & 1 \\
\hline 3 & 1,8 & 1 \\
\hline 3 & 2,0 & 1 \\
\hline
\end{tabular}

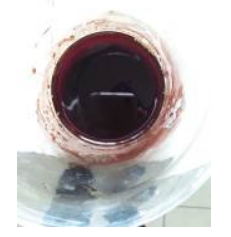

Figure 4. Synthesis of Copolymer Formaldehyde Recorcinol Tannin Products

\section{Physical Characteristics and Adhesive Chemical TRF}

The formaldehyde recorcinol tanninn resin which produced from this study has better adhesion and is ecofriendly when compared with synthetic adhesives (phenol resorcinol formaldehyde). The carbon chains formed in the tannin extract tend to be susceptible to degradation process if the environment among supports. Therefore, the addition of formaldehyde aims to make a polymerization bridge which the bonds tend to be more stable so that it can increase adhesive adhesion. Meanwhile, the addition of resorcinol aims as a feeder or initiator to bind a formaldehyde group that does not react with tannin, thus not cause formaldehyde emissions.

The use of resorcinol in tannin copolymerization enhances the reactivity of the reaction, so that the molecules contained in the resin are increasing. Thus, it is expected that more adhesive molecules will react with the wood during the bonding process, and create better adhesiveness. The physical and chemical characteristics of the synthetic TRF adhesives are presented in Table 2.

Table 2. Physical-Chemical Characteristics of Formaldehyde Tannin-Resalcinol Copolymerization

\begin{tabular}{|c|c|c|c|c|c|c|c|c|}
\hline \multirow[b]{2}{*}{ No } & \multirow[b]{2}{*}{$\begin{array}{c}\text { Characteristic } \\
\mathrm{s}\end{array}$} & \multicolumn{4}{|c|}{ TRF Composition } & \multirow{2}{*}{$\begin{array}{c}\text { TRF } \\
\text { Adhesive } \\
\text { (Santoso, } \\
2015\end{array}$} & \multirow{2}{*}{$\begin{array}{c}\text { FF } \\
\text { Standar } \\
\text { d (SNI, } \\
1998)\end{array}$} & \multirow{2}{*}{$\begin{array}{c}\text { PRF } \\
\text { Sythesis } \\
\text { Adhesive } \\
\text { (Santoso, } \\
\text { 2015) }\end{array}$} \\
\hline & & $3: 1,4: 1$ & $3: 1,6: 1$ & $3: 1,8: 1$ & $3: 2,0: 1$ & & & \\
\hline 1. & $\begin{array}{l}\text { Appereance } \\
\text { - Form } \\
\text { - Colour } \\
\text { - Bau }\end{array}$ & $\begin{array}{l}\text { Liquid } \\
\text { Browni } \\
\text { sh red } \\
\text { Fenol }\end{array}$ & $\begin{array}{l}\text { Liquid } \\
\text { Browni } \\
\text { sh red } \\
\text { Fenol }\end{array}$ & $\begin{array}{l}\text { Liquid } \\
\text { Browni } \\
\text { sh red } \\
\text { Fenol }\end{array}$ & $\begin{array}{l}\text { Liquid } \\
\text { Browni } \\
\text { sh red } \\
\text { Fenol }\end{array}$ & $\begin{array}{l}\text { Liquid } \\
\text { Brownis } \\
\text { h red } \\
\text { Fenol }\end{array}$ & $\begin{array}{l}\text { Liquid } \\
\text { Browni } \\
\text { sh red } \\
\text { Fenol }\end{array}$ & $\begin{array}{l}\text { Liquid } \\
\text { Brownis } \\
\text { h red } \\
\text { Fenol }\end{array}$ \\
\hline 2. & Visual & $\begin{array}{c}\text { No } \\
\text { solid } \\
\text { granule } \\
\text { s }\end{array}$ & $\begin{array}{c}\text { No } \\
\text { solid } \\
\text { granule } \\
\text { s }\end{array}$ & $\begin{array}{c}\text { No } \\
\text { solid } \\
\text { granule } \\
\text { s }\end{array}$ & $\begin{array}{c}\text { No } \\
\text { solid } \\
\text { granule } \\
\text { s }\end{array}$ & $\begin{array}{l}\text { No solid } \\
\text { granules }\end{array}$ & $\begin{array}{c}\text { No } \\
\text { solid } \\
\text { granule } \\
\text { s }\end{array}$ & $\begin{array}{l}\text { No solid } \\
\text { granules }\end{array}$ \\
\hline 3. & $\mathrm{pH}$ & 11,00 & 11,02 & 11,07 & 11,00 & 11,00 & $10-13,1$ & 8 \\
\hline 4. & $\begin{array}{l}\text { Viscosity } \\
\text { (Poise) }\end{array}$ & 2,46 & 2,82 & 2,94 & 3,17 & 5,6 & $1,0-3,0$ & 3,4 \\
\hline 5. & $\begin{array}{l}\text { Density } \\
(\mathrm{g} / \mathrm{mL})\end{array}$ & 1,174 & 1,176 & 1,180 & 1,188 & 1,14 & $\begin{array}{l}1,16- \\
1,2\end{array}$ & 1,15 \\
\hline 6. & $\begin{array}{l}\text { Solid Resin } \\
\text { Levels }(\%)\end{array}$ & 41,80 & 43,08 & 44,11 & 45,73 & 19,05 & $\begin{array}{l}40,00- \\
45,00\end{array}$ & 57,03 \\
\hline
\end{tabular}
Product

\section{Testing of Adhesive Firmness on Lamina Wood.}

The adhesive firmness test is used to determine the adhesive quality of TRF in the four composition ratios of lamina wood manufacture. In this study the adhesive strength of the resulting TRF adhesives was measured by applied to lamina wood using Autograph AG 10T instrument. Lamina wood making is done by way of two camphor wooden about $(10 \times 2,9 \times 0,2) \mathrm{cm}$ dried first in the oven until the water content reaches $12 \%$, then shriveled and sanded.

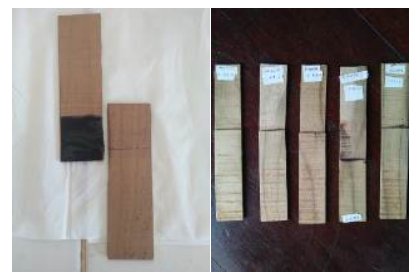

Figure 5. Lamina Wood Making Process from Kamper Wood

Next, the adhesive coating is carried on on one of the wood surfaces using a brush and left to 5-10 minutes for the adhesive seep into the wood. Then glued toward the fibers parallel and pressed for 3 hours to form a strong bond between two woods that are united.

The test with the Autograph AG 10T instrument was performed by flops of both ends of the specimen on the elongation device, then observed until both wooden blades were cut off then recorded the large weight force $(\mathrm{KgF})$ and a length $(\mathrm{mm})$ based on a tensile speed of 50 $\mathrm{mm} / \mathrm{min}$ [12]. The result of measurement of adhesive firmness can be seen in Figure 6 and Table 3.

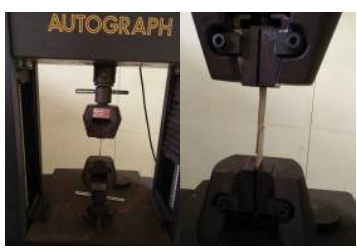

Figure 6. The Test of Adhesive Firmness Lamina Wood Using Autograf 
Table 3. Measurement Result of Adhesive Firmness Lamina Wood Using Autograf

\begin{tabular}{|c|c|}
\hline $\begin{array}{c}\text { The ratio of } \\
\text { TRF Adhesive } \\
\text { Composition }\end{array}$ & $\begin{array}{c}\text { Adhesive } \\
\text { Firmness Lamina } \\
\text { Wood Using } \\
\text { Autograph }(\mathrm{KgF})\end{array}$ \\
\hline $3: 1,4: 1$ & 71,05 \\
\hline $3: 1,6: 1$ & 102,35 \\
\hline $3: 1,8: 1$ & 66,00 \\
\hline $3: 2,0: 1$ & 59,25 \\
\hline
\end{tabular}

The adhesive firmness can be interpreted as the maximum shear load required to decide wood specimens divided by the cross-sectional area of lamina wood. The calculation results can be seen in Table 4.6

Table 4. Measurement Result of Adhesive Firmness Lamina Wood Using Autograph

\begin{tabular}{|c|c|}
\hline $\begin{array}{c}\text { The ratio of } \\
\text { adhesive TRF } \\
\text { Composition }\end{array}$ & $\begin{array}{c}\text { The adhesive } \\
\text { firmness value } \\
\left(\mathrm{kg} / \mathrm{cm}^{2}\right)\end{array}$ \\
\hline $3: 1,4: 1$ & 80,08 \\
\hline $3: 1,6: 1$ & 115,37 \\
\hline $3: 1,8: 1$ & 74,39 \\
\hline $3: 2,0: 1$ & 66,78 \\
\hline
\end{tabular}

The relation value graph of adhesive firmness lamina wood with resorcinol mass can be seen in Figure 7.

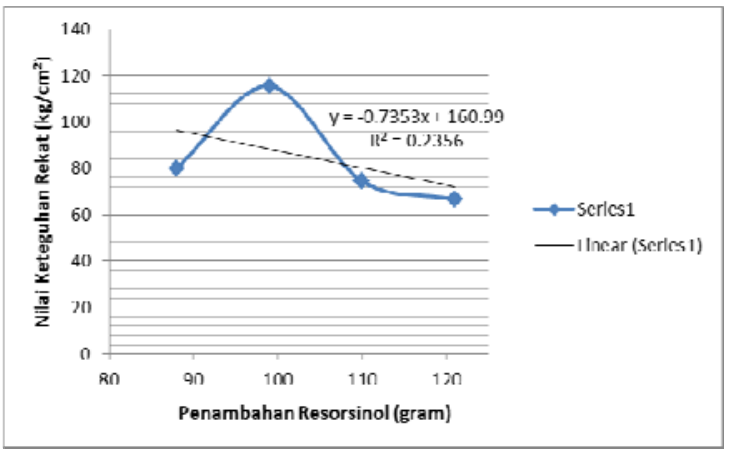

Figure 7. the graphics of Resorcinol addition for Adhesive Firmness of Lamina Wood.

Based on these data indicates that the result of whole TRF adhesive has fulfilled the criteria of the Indonesian National Standard for exterior quality as the value is more than $8 \mathrm{~kg} / \mathrm{cm} 2$ [13]. The highest adhesive firmness value was produced on the composition ratio TRF 3: 1.6: 1 about $115.37 \mathrm{~kg} / \mathrm{cm} 2$. The value of adhesive firmness of laminated wood with TRF adhesive is greater when compared with Synthetic Formaldehyde Recorcinol Fenol (PRF) which yields a adhesive firmness value about $54.97 \mathrm{~kg} / \mathrm{cm}^{2}$ for laminated wood products from low density woods is Sengon wood. While the use of synthetic PRF adhesives in mediumdensity woods such as Sungkai, Mangium, Rubber, and Mahogany yields a firmness of $44.09 \mathrm{~kg} / \mathrm{cm}^{2}$, and in high density woods such as Kempas and Merbau yields about $36.24 \mathrm{~kg} / \mathrm{cm} 2$ of firmness [7].
In the Santoso (2015) research, the quality of lamina boards which glued using TRF adhesives from Merbau wood waste extract yielded the highest adhesive firmness of $65.30 \mathrm{~kg} / \mathrm{cm}^{2}$, on the Sengon wood species [7]. When referring to the Japanese Standard [14] the adhesive firmness value of TRF on the composition ratio of 3: 1.6: 1 is corresponding with the Japanese standard because the value is more than $96 \mathrm{~kg} / \mathrm{cm}^{2}$. So that, it can be expressed that the TRF adhesive made in the $3: 1$ : 6: 1 ratio is the best TRF composition because it has better adhesion power than the PRF synthetic adhesive and produces a adhesive firmness accordance with SNI standard (1998) and JAS standard (1996) .

The graph of Figure 7 shows the highest adhesive firmness value obtainedfrom the composition of TRF 3: 2.0: 1 with the addition of resorcinol of 99 grams and then decreased in addition of 110 grams and 121 grams of resorcinol. This proves that the more addition of resorcinol in the adhesive formulation, the resulting adhesive firmness will also increase to a certain extent of addition, in this case at the addition of 99 gram of resorcinol

The decreasing value of firmness laminated wood is due to the higher viscosity of the resulting TRF adhesive. The higher viscosity causes the adhesive to flow slowly and the penetration into the venir becomes shallower [15]. This condition causes the bond between adhesive molecules with lamina wood weaken, so the value of firmness decreases. According to Maloney (1993) adhesives whose viscosity values is corresponding will make the adhesive able to penetrate the wood pores properly and become an optimum bond. The adhesive will produce good adhesion [16].

\section{CONCLUSIONS}

Based on the result and discussions that have been presented, it can be concluded that from the testing results of firmness of laminated wood obtained the best value in the composition ratio of $3: 1,6: 2$ that is equal to 115,37 $\mathrm{kg} / \mathrm{cm}^{2}$ with formaldehyde emission levels to $0.295 \mathrm{mg} / \mathrm{l}$ corresponding to SNI 06-4567-1998.

\section{ACKNOWLEDGMENT}

Thanks to Dra. Aniek Setiya Budiatin, Apt., M.S. from Airlangga University who has guided the process of testing of adhesive firmness on lamina wood using the Autograph instrument.

\section{REFERENCES}

[1] Juliati, Raudhah. 2009. Pengaruh Waktu Kempa dan Kadar Ekstender terhadap Sifat Fisis Mekanis Venir Bambu Lamina Dengan Perekat Fenol Formaldehid. Bogor: Institut Pertanian Bogor.

[2] Puspita Risya. 2008. Papan Partikel Tanpa Perekat Sintetis (Binderless Particle Board) Dari LimbahIndustri Penggergajian. Bogor: Institut Pertanian Bogor

[3] Wenger, K. F. 1984. Forest Handbook.Willey. New York: Interscience Publication John Wiley and Sons.

[4] Sucipto, Tito. 2009. Perekat Lignin. Sumatera Utara: Fakultas Pertanian Universitas Sumatera Utara. 
[5] Surdiding, Ruhendi. 2007. Analisis Perekatan Kayu. Bogor: Fakultas Kehutanan IPB.

[6] Kardono, L. Broto S. 2000. Kajian etnobotani dan fitokimia tumbuhan johar (Cassia siamea Lamk., Leguminosae. Bogor: Pusat Penelitian Biologi, LIPI.

[7] Santoso, Adi. 2015. Kualitas Papan Lamina dengan Perekat Resorsinol dari Ekstrak Limbah Kayu Merbau. Bogor: Pusat Penelitian dan Pengembangan Hasil Hutan.

[8] Santoso, Adi. 2003. Sintesis dan Karakterisasi Resin Lignin Resorsinol Formaldehida untuk Perekat Kayu Lamina. [Disertasi]. Bogor: Fakultas Pascasarjana Institut Pertanian Bogor.

[9] Santoso, Adi. 2004. Sintesis dan Karakterisasi Resin Lignin Resorsinol Formaldehida Sebagai Perekat Kayu Lamina. Bogor: Puslitbang Teknologi Hasil Hutan.

[10] Septa, Arie Fajar. 2001. Introduksi Penggunaan Perekat Alternatif Untuk Kayu Laminasi. Bogor: Institut Pertanian Bogor.

[11] Suyatno dan Dayanti, Rini

2012. Aktivitas Antioksidan Ekstrak Metanol Bagian Batang Tumbuhan Paku Nephrolepis radicans (BURM). KUHN. Unesa Journal of Chemistry. Vol. 1, No. 1, Hal 90.
[12] Suyatno dan Ariska, Rizani Eka. 2015. Pembuatandan Karakterisasi Edible Film Dari Pati Bonggol Pisang dan Karagenan Dengan Plasticizer Gliserol Sebagai Bahan Pengemas Makanan. [Skripsi]. Surabaya: Jurusan Kimia Universitas Negeri Surabaya

[13] Standar Nasional Indonesia (SNI). 1998. Kumpulan SNI Perekat. Jakarta: Badan Standardisasi Nasional.

[14] Japanese Agricultural Standard (JAS). 1996. Japanese Agricultural Standard for Structural Glued Laminated Timber. Tokyo: JPIC

[15] Santoso, A., Achmadi, S.S., Sudohadi, Y., dan Sujanto. 1997. Pengaruh Penambahan Tanin Pada Fenol Formaldehida Terhadap Sifatnya Sebagai Perekat Kayu Lapis. Bogor: Puslitbang Teknologi Hasil Hutan.

[16] Maloney, T.M. 1993. Modern Particle Board an dry Proces Fiberboard Manufacturing. San Fransisco: Miller Freeman Inc. 